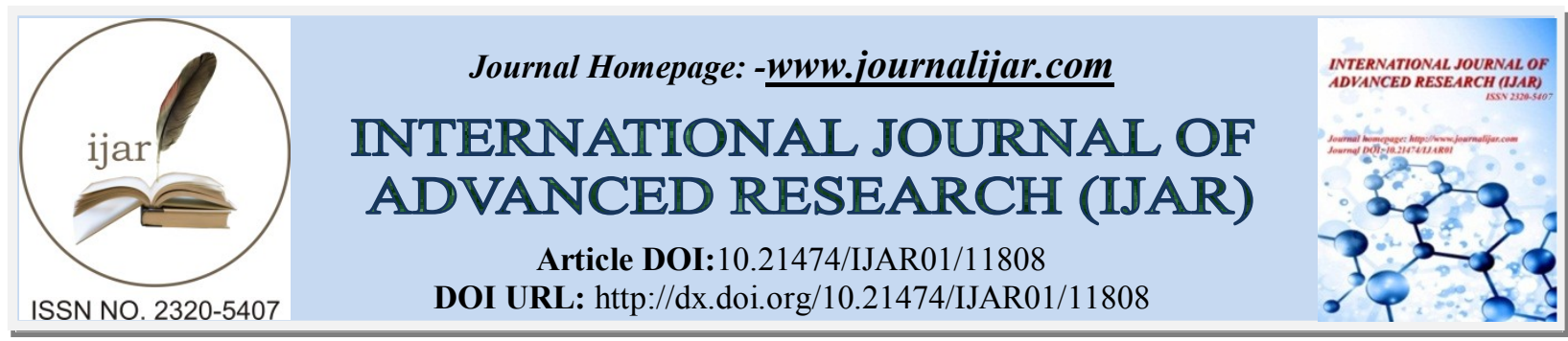

RESEARCH ARTICLE

\title{
CHARACTERIZATION OF PHYSICOCHEMICAL PROPERTIES AND BIOACTIVE COMPOUNDS OF OIL FROM NASCENT SEEDS OF AZADIRACHTA INDICA
}

\author{
Samuel Atabo ${ }^{1}$, Zara Muhammad ${ }^{2}$ and Kurmi Ann Pyeng ${ }^{3}$ \\ 1. Department of Biochemistry, University of Agriculture, Makurdi, Benue State, Nigeria. \\ 2. Department of Applied Science, College of Science and Technology, Kaduna Polytechnic, Kaduna, Nigeria. \\ 3. Department of Nutrition and Dietetics, College of Science and Technology, Kaduna Polytechnic, Kaduna, \\ Nigeria.
}

\section{Manuscript Info}

Manuscript History

Received: 26 July 2020

Final Accepted: 31 August 2020

Published: September 2020

Key words:-

Physicochemical, Azadirachta Indica,

Characterization, Oil

\begin{abstract}
Depending on composition, fatty acids of plant sources are explicitly useful in food, chemical and pharmaceutical industries. The present study characterizes Soxhlet extracted neem seed oil by determination of physicochemical properties and bioactive compounds. Extraction involved the use of solvent semi-continuous extraction method for 6 hours with N-hexane. Percentage Oil yield was at 39. Saponification value $(50.490 \mathrm{mgKOH} / \mathrm{g})$, Iodine value $(50.28 \mathrm{~g} / 100 \mathrm{~g})$, Acid value $(5.610 \mathrm{mgKOH} / \mathrm{g})$, Free fatty acid $(2.805 \mathrm{w} / \mathrm{w})$, Peroxide value $(62.75 \mathrm{meq} / \mathrm{kg})$ and Specific gravity $(0.948)$ were determined. Density at $25^{\circ} \mathrm{C}$, Flash point, boiling point, melting point, colour and Odour provided supportive information to the major physicochemical properties analyzed. Gas Chromatography - Mass Spectrometry (GCMS) of the Soxhlet extracted Neem Seed oil showed different peak values of industrially essential compounds such as 7-Pentadecyne, Glycidyl palmitate, Oleic Acid, 9,12-Octadecadienoic acid and methyl ester (Omega-6 acid). Saponification value was found to be high, suggesting the presence of FFA with low molecular weight, which brands the oil as essential in cosmetic and food industries. Low Iodine value and low total acidity seems to consolidate the usefulness of neem seed oil in cosmetic industries. Conversely, the high peroxide level makes it unsuitable for cooking. It may therefore be inferred that Soxhlet extracted Azadirachta indica seed may be industrially viable but less suitable for consumption.
\end{abstract}

Copy Right, IJAR, 2020,. All rights reserved.

\section{Introduction:-}

Azadirachta indica (Neem) which belongs to the family Meliaceae, an evergreen plant of the tropics and sub-tropics, and native to the Indian subcontinent with demonstrated ethnomedicinal value and importance in agriculture as well as in the pharmaceutical industry (Kharwar et al., 2020). It known as Dogon yaro or Darbejiya in Hausa (Ibrahim, et al., 2020) and is reported to have antiplasmodial, antitrypanosonal, antibacterial, antiviral, larvicidal and fungicidal activities (Atawodi and Atawodi, 2009). 
Various parts of the Neem tree, including the seeds, leaves, bark, fruit, flowers, oil, and gum are associated with the treatment of medical conditions such as cancer, hypertension, heart diseases, and diabetes. The potential effect that are seen when using these extracts can certainly be attributed cellular and molecular mechanisms, these mechanisms include free radical scavenging, detoxification, DNA repair, cell cycle alteration, programmed cell death mitigation and autophagy,immune surveillance, anti-inflammatory, anti-angiogenic, and anti-metastatic activities and the ability to modulate of various signalling pathways (Jose et al., 2020).

Essential oils such as the Soxhlet extracted Azadirachta indica seed oil obtained from the neem plant seeds purportedly presents low risk to the environment and human health when utilized industrially and for medicinal purpose. It is arguably the most important part of the plant in terms multiplicity of utilization.

The increasing demand for essential oil as a promising option to replace "toxic" synthetic oil for effective economic use and industrial utilization has poses a challenge. Essential oils are complex volatile compounds, extracted from specific plant species, with promising therapeutic potentials (Atta ur, et al., 2019), attributable to biologically active secondary metabolites and bioactive compounds (Atawodi and Atawodi, 2009, Ibrahim et al., 2020).

The aim of this study is to characterize Soxhlet extracted neem seed oil using Gas Chromatography linked Mass Spectrometry (GCMS), and to determine the physicochemical characteristics of the oil as a means of evaluating the quality and presumptive pharmacological, industrial and nutritional utilization.

\section{Material And Methods:- \\ Material:}

Equipment:

Analytical balance, Filter paper, Heating Mantle, Soxhlet chamber, Conical flasks, Volumetric flasks, Burette, measuring cylinder, $360^{\circ} \mathrm{C}$ thermometer, Flat bottom flask, Hand gloves, spatula, sample bottle, stopper, measuring cylinder, retort stand andmicro-pipette were used.

\section{Reagents:}

N-hexane, Potassium hydroxide $(\mathrm{KOH})$, Hydrochloric acid $(\mathrm{HCl})$, Chloroform, Starch solution, Ethanol, Potassium Iodide, Sodium Thio-sulphate, Wijs solution, Petroleum ether, Phenolphthalein indicator and distilled water were used to carry out the physicochemical analysis.

\section{Collection of Plant material:}

The plant material consisted of some nascent neem seeds (Azadirachta indica). These seeds coming from mature fruits, collected at a plantation around the Federal University of Agriculture Makurdi, Benue state, Nigeria. The plant material was identified by Mr. Namadi Sanusi at the Herbarium of the Department of Biological science, Ahmadu Bello University, Zaria, Kaduna state with a voucher number of 900151 . The seed is then spread to enhance drying at room temperature and kept in a well-sealed plastic jar until extraction.

\section{Methods:-}

\section{Azadirachta indica Seed Preparation:}

The harvested Neem seeds were first decorticated, washed, sun-dried and foreign material removed by winnowing. Pestle and Mortar were used to crush the seeds into a paste (cake) to enhance extraction.

\section{Extraction of oil content from Seeds of the Azadirachta indica:}

The oils of the Azadirachta indica seeds were extracted by solvent semi-continuous extraction method (using Soxhlet chamber) for 6 hours with n-hexane (Kittiphoom and Sutasinee et al., 2013). The Soxhlet apparatus comprises of three components: Round bottom flask, sohxlet chamber and the condenser. The three components are set up using a retort stand on a thermostated heating mantle, a $250 \mathrm{ml}$ of $\mathrm{N}$-hexane was measured into the round bottom flask and heated at $40^{\circ}-60^{\circ} \mathrm{C}$ and the vapour passes through the vapour tube into the reflux condenser. The vapour condenses and drops into the porous thimble containing about $20 \mathrm{~g}$ of Neem cake (crushed seed) material to be extracted, the condensed liquid gradually trickles down the content of the thimble, this extract accumulates in the chamber and passes into the siphon tube and gradually rises up to the point of dripping into the round bottom flask. The process continues for the specified time. The final extract gets collected into the round bottom flask which is allowed in an open air, the N-Hexane (solvent) evaporates leaving only the oil (Abdulhamid et al., 2014). The oil 
was then stored under optimum temperature for subsequent physicochemical analyses, and further characterized and differentiated by GC-MS and FT-IR spectroscopy.

$$
\begin{gathered}
\text { Percentage yield }(\%)=\frac{\text { Weight of Oil }}{\text { Weight of Original sample }} \times 100 \\
\text { Weight of original sample: } 20 \mathrm{~g} \text {, Weigh of oil: } 7.8 \mathrm{~g} \\
\% \text { yield }=\frac{7.8 \mathrm{~g}}{20 \mathrm{~g}} \times 100 \quad=39 \%
\end{gathered}
$$

\section{Determination of Physicochemical Properties:}

The Acid and Peroxide values were evaluated by modified methods described by Desta et al., 2020. Free fatty acid (FAA), Iodine value and saponification value were determined by the method of Murthy et al., 2016.

\section{Specific Gravity:}

The specific gravity bottle was oven dried to remove existing moisture after which its mass (empty) was measured and recorded. It was then filled with $10 \mathrm{ml}$ of water and its mass measured and recorded. The specific gravity bottle was then filled individually with equal volume of each oil extract while its mass was measured and recorded in each case. The specific gravity of individual oil extracts was calculated using the formula below:

Specific gravity $=\frac{W_{1}-W_{2}}{W_{3}-W_{2}}$

Where, $\mathrm{W} 1=$ Mass of specific gravity bottle + Oil extract

$\mathrm{W} 2$ = Mass of empty specific gravity bottle, W3 = Mass of specific gravity bottle + Water

\section{Density:}

The density was obtained using the formula below:

Density $=$ Specific gravity $\times 1000 \mathrm{~kg} / \mathrm{m}-$

\section{Boiling Point:}

Neem oil was poured into a beaker and gently heated using the heating mantle. As the oil begins to boil, a thermometer was inserted and the temperature reading was taken in degree Celsius $\left({ }^{\circ} \mathrm{C}\right)$.

\section{Melting Point:}

The freeze Neem seed oil in a beaker was placed in a heating water bath and observed as the oil starts to melt, a thermometer was inserted into it and the melting temperature of the oil was recorded in degree Celsius $\left({ }^{\circ} \mathrm{C}\right)$.

\section{Flash point:}

The oil was poured into a clean conical flask and placed on a heating mantle, as the oil begins to boil; a thermometer was inserted, as the test flame was applied. The flash point is the temperature indicated by the thermometer at the time the oil vapor lights up or flashes.

\section{Characterization of Azadirachta indica seed oil composition:}

The Azadirachta indica seed oilcomposition was determined by Gas chromatography- Mass Spectrometry (GC-MS) as per the method and conditions described by Aneesh et al., 2013.

\section{Results:-}

\section{Physicochemical Properties:}

The Soxhlet extracted Neem seed oil was analyzed by evaluating the physicochemical properties such as Acid value, Free fatty acid, Saponification, Peroxide value, Iodine value, Specific gravity, Density at $25^{\circ} \mathrm{C}$, Flash point, Boiling point, Melting Point, Colour, and Odour. 
Table 1:- Physicochemical Characteristics of Soxhlet Extracted Neem Seeds Oil.

\begin{tabular}{|l|ll|l|}
\hline S/No & \multicolumn{1}{|c|}{ Units } & Results \\
\hline 1. & Acid value & \multicolumn{1}{|c|}{$(\mathrm{mgKOH} / \mathrm{g})$} & $5.610 \pm 0.86$ \\
\hline 2. & Free fatty acid $\quad(\% \mathrm{w} / \mathrm{w})$ & $2.805 \pm 0.18$ \\
\hline 3. & Saponification $\quad(\mathrm{mgKOH} / \mathrm{g})$ & $50.490 \pm 2.19$ \\
\hline 4. & Peroxide value $(\mathrm{meq} / \mathrm{kg})$ & $62.750 \pm 3.43$ \\
\hline 5. & Iodine Value $\quad(\mathrm{g} / 100 \mathrm{~g})$ & $60.280 \pm 4.51$ \\
\hline 6. & Specific gravity & 0.948 \\
\hline 7. & Density at $25^{0} \mathrm{C} \quad\left(\mathrm{kg} / \mathrm{m}^{3}\right)$ & 948 \\
\hline 8. & Flash point $\quad\left({ }^{0} \mathrm{C}\right)$ & 286 \\
\hline 9. & Boiling point $\quad\left({ }^{0} \mathrm{C}\right)$ & 254 \\
\hline 10. & Melting point $\left({ }^{0} \mathrm{C}\right)$ & 18 \\
\hline 11. & Colour $\quad$ & Light brown \\
\hline 12. & Odour & Garlic \\
\hline
\end{tabular}

Table 2:- GC-MS of Soxhlet Extracted Neem Seed Oil.

\begin{tabular}{|l|l|l|l|l|}
\hline $\mathrm{S} / \mathrm{N}$ & Compound name & $\begin{array}{l}\text { Retention time } \\
(\mathrm{RT})\end{array}$ & Area \% & Quality \\
\hline 1. & 7-Pentadecyne & 35.331 & 0.52 & 96 \\
\hline 2. & $\begin{array}{l}\text { Cyclopropaneoctanal, } \\
\text { 2-octyl-7-Pentadecyne }\end{array}$ & 35.056 & 1.04 & 90 \\
\hline 3. & Cis-9-Hexadecenal & 34.538 & 7.02 & 60 \\
\hline 4. & $9,17-$ Octadecadienal & 34.269 & 30.53 & 89 \\
\hline 5. & Cyclopropaneoctanal & 33.993 & 0.24 & 93 \\
\hline 6. & 14-Methyl-8-hexadecyn-1-ol & 33.686 & 1.83 & 96 \\
\hline 7. & $9,17-$ Octadecadienal & 33.044 & 0.15 & 93 \\
\hline 8. & Glycidyl palmitate & 32.024 & 6.51 & 87 \\
\hline 9. & Oleic Acid & 31.435 & 1.72 & 95 \\
\hline 10. & $9,17-$ Octadecadienal & 30.284 & 47.40 & 95 \\
\hline 11. & $9,12-$ Octadecadienoic acid, methyl ester (Omega- 6 acid) & 29.299 & -1.17 & 99 \\
\hline 12. & Cyclopentadecanone, & 27.699 & 0.56 & 96 \\
\hline 13. & Methyl 10-methyl-hexadecanoate & 26.787 & 0.28 & 96 \\
\hline
\end{tabular}

\section{Discussion:-}

Physico-chemical characterization of Soxhlet extracted neem seed oil has revealed unique properties that provides information used to assess the quality and functionality of the oil (Jinfeng et al., 2011). Saponification value, Peroxide value, Acid value, Iodine value, Free fatty acid, Flash point, Specific gravity, density, boiling point, melting point, colour and odour were appraised.

The physico-chemical analyses showed high saponification number $50.490 \mathrm{mgKOH} / \mathrm{g}$. Dosunmu and Ochu (1995) reported an inverse relationship between saponification number and weight of fatty acids in the oil. Since oils that contain a great number of fatty acids of low molecular weight are crucial in cosmetic and food industries (Konushkan et al., 2019; Desta et al., 2020), the neem seed may suggestively be of great importance.

Generally, oils with peroxide levels higher than 10 meq $\mathrm{O}_{2} / \mathrm{kg}$ are considered to be less stable, and have short shelf life (Konushkan et al., 2019). Furthermore, oils with peroxide value higher than 9 meq $\mathrm{O}_{2} / \mathrm{kg}$ cause undesirable health problems by increasing reactive oxygen species as well as secondary products of lipid peroxidation that stimulate cardiovascular and inflammatory diseases (Lobo et al., 2010). The peroxide value of Soxhlet extracted neem seed oil averaged 62.750 meq $\mathrm{O}_{2} / \mathrm{kg}$. This perhaps suggest that the oil has high chance of becoming rancid, and may therefore be unsuitable for cooking.

Total acidity, expressed as Acid value, measures the extent to which glycerides in oil are decomposed by lipases. The Soxhlet extracted Neem seed oil has low Acid value of $5.610 \mathrm{mgKOH} / \mathrm{g}$. Relatively low Acid values is most suitable (in soap making) for industrial purposes (Onyeike et al., 2002), as it is the preferred quality control parameter used by paint manufacturers to monitor the concentrations of acids in resins (Ekpa and Ekpe, 1995). 
The Iodine value of an oil is used as an indicator for degree of unsaturation (Pomeranz and Meloan, 1987; Nielson, 1994). Low iodine value $(\leq 80.3)$ in oil could make it suitable for soap making whereas higher Iodine values are used in paint industries (Konushkan et al., 2019). The Iodine value of the present study is $60.280 \mathrm{~g} / 100 \mathrm{~g}$, which is in agreement with Konushkan et al., 2019 and potentially validates the local use of neem seed oil in Africa, as a component of Hair cream and soaps.

Free Fatty Acids (FFA) are analytically used to detect the level of unesterified fatty acid in a lipid sample to define its quality (Desta et al., 2020). In conjunction with acid and saponification values, FFA can also be used to give a measure of the amount of neutral fat (Desta et al., 2020). According to the present study, the low free fatty acid value of neem seed oil (2.81\%) fits in to the class of highly graded lipid or lipids with high quality (Overhults, et al., 1994; Desta et al., 2020)

Gas Chromatography - Mass Spectrometry (GC-MS) study of the Soxhlet extracted Neem Seed Oil shows different peak values of bioactive chemical compounds such as 7-Pentadecyne, Cyclopropaneoctanal, 2-octyl-7-Pentadecyne, Cis-9-Hexadecenal, 9,17-Octadecadienal, Cyclopropaneoctanal, 14-Methyl-8-hexadecyn-1-ol, 9,17-Octadecadienal, Glycidyl palmitate, Oleic Acid, 9,17-Octadecadienal, 9,12-Octadecadienoic acid, methyl ester (Omega-6 acid), and Methyl 10-methyl-hexadecanoate. They are mostly utilized in Food, Cosmetic and pharmaceutical industries.

\section{References:-}

1. Abdulhamid Abubakar, Sani Ibrahim, Fakai I. Musa, (2014). Physicochemical Analysis of Soxhlet Extracted Oils from Selected Northern Nigerian Seeds. Engineering and Technology International Journal of Bioengineering and Life Sciences. Vol:8, No:11.

2. Aneesh, T.P.,Thomas, E., Thomas D.G., Amanda, R. (2013). GC-MS Analysis of Phytochemical

3. Compounds Present in the Rhizomes of Nervilia aragoana Gaud. Asian Journal of Pharmaceutical and Clinical Research, 6(3): 68-74.

4. Atta ur Rehman Khan, Muhammad Nadeem, M. Aqeel Bhutto, Fan Yu, Xianrui Xie, Hany El-Hamshary, Ayman El-Faham, Usama A. Ibrahim and Xiumei Mo, (2019). Physico-Chemical and Biological Evaluation of PLCL/SF Nanofibers Loaded with Oregano Essential Oil. Pharmaceutics, 11, 386.

5. Dilsat Bozdogan Konuskan, Mehmet Arslan, Abdullah Oksuz, (2019). Physicochemical properties of cold pressed sunflower, peanut, rapeseed, mustard and olive oils grown in the Eastern Mediterranean region. Saudi Journal of Biological Sciences 26 (2019) 340-344.

6. Dosunmu, M. I., and Ochu, C. (1995). Physicochemical properties and fatty acid composition of lipids extracted from some Nigerian fruits and seeds. Global Journal of Pure and Applied Sciences, 1(1/2), 45-50.

7. Ekpa, O. D., and Ekpe, U. J. (1995). The effects of coconut oil concentration and air exposure to the total acidity of palm oil. Global. Journal of Pure and Applied Sciences, 1(1/2), 51-58.

8. Eugene N. Onyeike, Gloria N. Acheru. (2002). Chemical composition of selected Nigerian oil seeds and physicochemical properties of the oil extracts. Food Chemistry, 77 (2002) 431-437.

9. Ibrahim Sani1, Rabi'u Aliyu Umar, Sanusi Wara Hassan, Umar Zaki Faruq, Fatima Bello, Habiba Aminu and Amina Sulaiman. (2020). Hepatoprotective Effect of Azadirachta indica Leaf Fractionated Extracts against Snake Venom Toxicity on Albino Rats. Saudi Journal of Biomedical Research. Pp $112-117$.

10. Jose Francisco Islasa, Ezeiza Acostab, Zuca G-Buentelloa, Juan Luis Delgado-Gallegosa, Maria Guadalupe Moreno-Trevinoc, Bruno Escalantec, Jorge E. Moreno-Cuevas. (2020). An overview of Neem (Azadirachta indica) and its potential impact on health. Journal of Functional Foods 74; 104171

11. Kittiphoom S. and Sutasinee S, (2013). Mango Seed Kernel Oil and its Physicochemical Properties. International Food Research Journal; 20:1145-1149.

12. Jinfeng, P. Huixing, S., Juan Y., Yongkang, L., (2011). Changes in physiochemical properties of myofibrillar protein from silver Carp (Hypophthalmichthys Mollitrix) during heat treatment. J. Food Biochemistry, 35 (3), 939-952.

13. Lobo, V., Patil, A., Phatak, A., Chandra, N., (2010). Free radicals, antioxidants and functional foods: Impact on human health. Pharmacognosy Review. 4, 118-126.

14. Mulugeta Destaa, Andualem Mollab, Zekeria Yusuf., (2020). Characterization of physico-chemical properties and antioxidant activity of oil from seed, leaf and stem of purslane (Portulaca oleracea L.) Biotechnology Reports 27: e0 - 0512

15. Murthy, H.N., Joseph, K.S., Madiwal, A., Rajan, G.D., Badiger, M., Kolkar, L., Hiremath,

16. R., Shirugumbi, M. (2016). Chemical composition and fatty acid profile of Khat (Catha edulis)

17. seed oil. Journal of the American Oil Chemists' Society. 93(3): 405-409. 
18. Nielson, S.S., (1994). Introduction to the Chemical Analysis of Foods. Chapman and Hall, New York, pp. $93-$ 207.

19. Overhults DG, et al. (1994). Effect of Heated Air Drying on Soybeans Oil Quality and Free Fatty Acid. Transaction of the ASAE.;72:150.

20. Pomeranz, Y., Meloan, C.E., (1987). Food Analysis: Theory and Practice. Van Nostrand Reinhold Company, New York, pp. 81-765.

21. Ravindra N. Kharwar, Vijay K. Sharma, AshishMishra1, Jitendra Kumar, Dheeraj K. Singh1, Satish K. Verma, Surendra K. Gond, Anuj Kumar, Nutan Kaushik, Bharadwaj Revuru, Souvik Kusari. (2020). Harnessing the Phytotherapeutic Treasure Troves of the Ancient Medicinal Plant Azadirachta indica (Neem) and Associated Endophytic Microorganisms. Planta Med. 1- 35.

22. Sunday E. Atawodi and Joy C. Atawodi. (2009). Azadirachta indica (neem): a plant of multiple biological and pharmacological activities. Phytochem Rev. 8:601-620. 